\title{
RELACJE MIĘDZY SEKTOREM PUBLICZNYM I SEKTOREM POZARZĄDOWYM W SFERZE WYKONYWANIA ZADAŃ PUBLICZNYCH
}

\author{
Dorota Strus \\ Zakład Nauk Administracyjnych, \\ Uniwersytet Przyrodniczo-Humanistyczny w Siedlcach, \\ ul. Bema 1, 08-110 Siedlce \\ e-mail: dorotastrus@interia.pl
}

\begin{abstract}
Streszczenie: Celem opracowania jest wskazanie aktualnego modelu współdziałania pomiędzy jednostkami samorządu terytorialnego, a przedstawicielami trzeciego sektora w przedmiocie realizacji zadań o charakterze publicznym na podstawie badań przeprowadzonych z inicjatywy Departamentu Pożytku Publicznego w Ministerstwie Pracy i Polityki Społecznej oraz badań własnych autora. Analiza relacji międzysektorowych z perspektywy administracji samorządowej zostanie oparta na przeprowadzonych badaniach terenowych. Uzyskane wyniki badań w ocenie autora opracowania uprawniają do sformułowania kilku tez. Po pierwsze istniejący model współdziałania pomiędzy sektorem publicznym, a sektorem pozarządowym w zasadzie ogranicza się do ustawowego zlecania zadań publicznych podmiotom niepublicznym w powtarzających się obszarach działalności tj. w zakresie sportu, turystyki rekreacji. Po drugie współpraca w najmniejszych jednostkach podziału terytorialnego państwa (gminach) wydaje się być najsłabsza. Po trzecie przedstawiciele administracji samorządowej nie stosują niektórych rozwiązań wynikających z ustawy o działalności pożytku publicznego i wolontariacie. Po czwarte współpraca międzysektorowa nie uwzględnia realizacji wspólnych projektów z wykorzystaniem środków pochodzących ze źródeł zewnętrznych. Po piąte niedoskonałości w zakresie podejmowanej współpracy międzysektorowej wynikają z braku kultury współdziałania, niewystarczającej wiedzy o specyfice działania organizacji pozarządowych. Ostatnia teza poddana weryfikacji w opracowaniu dotyczy wskazania pozytywnych zmian w obowiązującym modelu współdziałania.
\end{abstract}

Słowa kluczowe: organizacje pozarządowe, administracja samorządowa, zadania publiczne, współpraca międzysektorowa, społeczeństwo obywatelskie

\section{UWAGI WSTĘPNE}

Współpraca międzysektorowa i budowanie wzajemnych relacji pomiędzy przedstawicielami administracji samorządowej i przedstawicielami sektora pozarządowego znajduje swoje umocowanie w przepisach ustawy z dnia 24 kwietnia 
2003 roku o działalności pożytku publicznego i wolontariacie. Konsekwencją jej uchwalenia było wprowadzenie do przepisów ustaw ustrojowych dotyczących funkcjonowania samorządu terytorialnego rozwiązań w zakresie obowiązku nawiązywania współpracy z przedstawicielami organizacji pozarządowych. Zaznaczyć należy, że włączenie organizacji pozarządowych w procesy związane z wykonywaniem zadań publicznych i kreowaniem polityk publicznych było wyrazem kształtowania się społeczeństwa obywatelskiego opartego na zasadzie partycypacji i współodpowiedzialności w przedmiocie szeroko rozumianych spraw publicznych. Organizacje pozarządowe wpisują się zatem w kanon współczesnego społeczeństwa obywatelskiego. W myśl tego stwierdzenia podstawową ideą społeczeństwa obywatelskiego jest zdolność do samodzielnego organizowania się w celu realizacji określonych i uzasadnionych społecznie potrzeb. Jak podkreśla E. Wnuk-Lipiński pod pojęciem społeczeństwa obywatelskiego należy rozumieć ogół niepaństwowych instytucji, organizacji i stowarzyszeń cywilnych działających w sferze publicznej. Tworzą go struktury względnie autonomiczne wobec państwa, powstające oddolnie i charakteryzujące się na ogół dobrowolnym uczestnictwem swoich członków. ${ }^{1}$ Społeczeństwo obywatelskie należy utożsamiać po pierwsze z czynnikiem aktywności obywatelskiej oraz z istnieniem świadomości obywatelskiej, która nakazuje kształtowanie więzi społecznego zaufania i współpracy na rzecz dobra powszechnego. Idąc za M. Barańskim organizacje pozarządowe oraz inne wspólnoty lokalne, a także nieformalne grupy społeczne wypełniają przestrzeń pomiędzy jednostką a społeczeństwem oraz między obywatelem a państwem. ${ }^{2}$ Postrzeganie organizacji pozarządowych, jako pewnego ogniwa łączącego państwo z obywatelami sprawia, że uzyskują one status ważnego aktora w przestrzeni publicznej, który wpływa na kreowanie procesów decyzyjnych przez podmioty władzy publicznej. Z kolei według H. Izdebskiego trzeci sektor tworzy pewien układ społeczny występujący obok sektora władz publicznych oraz sektora przedsiębiorców. ${ }^{3}$ Należy podkreślić, że budowanie partnerstwa publiczno-społecznego wpisuje się w realizację koncepcji governance. Zakłada ona, że proces sprawowania władzy i podejmowania decyzji w kontekście realizacji zadań publicznych jest oparty na wzajemnych relacjach zróżnicowanych podmiotów. Co w konsekwencji ma przyczynić się do zwiększenia efektywności w wykonywaniu zadań obejmujących sferę publiczną i tym samym przynieść większą satysfakcję po stronie odbiorców usług publicznych. ${ }^{4}$ Proces kształtowania i budowania relacji pomiędzy sektorem pozarządowym, a sektorem publicznym jest implikowany

1 E. Wnuk-Lipiński, Socjologia życia publicznego, Wydawnictwo Naukowe Scholar, Warszawa 2005, s. 119.

2 M. Barański, Organizacje pozarządowe w społeczeństwie obywatelskim (www. ngo.edu. pl/skrypt/I.doc), s. 13 .

3 Szerzej M. Halszka Kurleto, Organizacje pozarządowe w działalności pożytku publicznego, Wydawnictwo LexisNexis Warszawa 2008.

4 A. Kołomycew, B. Kotarba (red.), Partnerstwa w sferze publicznej, Wydawnictwo Naukowe Scholar, Warszawa 2014, s. 9. 
przepisami prawa i powinien odbywać się z poszanowaniem ustawowych zasad i form współpracy międzysektorowej. Jakość współdziałania w przedmiocie wykonywania zadań publicznych jest zależna od aktywności obydwu aktorów występujących w przestrzeni publicznej a przede wszystkim od budowania dobrych praktyk i kultury współdziałania. Analiza relacji pomiędzy sektorem publicznym i sektorem pozarządowym w kontekście wykonywania zadań publicznych zostanie przeprowadzona $\mathrm{w}$ oparciu o obowiązujące przepisy prawa zawarte $\mathrm{w}$ ustawie z dnia 24 kwietnia 2003 roku o działalności pożytku publicznego i wolontariacie oraz z wykorzystaniem uzyskanych wyników badań terenowych.

\section{PROCES KSZTAŁTOWANIA RELACJI MIĘDZY SEKTOREM PUBLICZNYM, A SEKTOREM POZARZĄDOWYM. UWARUNKOWANIA PRAWNE I SPOŁECZNO-POLITYCZNE}

Obowiązek w zakresie podejmowania współpracy pomiędzy podmiotami administracji samorządowej, a organizacjami pozarządowymi znajduje aktualnie swoje umocowanie w przepisach ustawy z dnia 24 kwietnia 2003 roku o działalności pożytku publicznego i wolontariacie. ${ }^{5}$ Początki współpracy między sektorem publicznym, a sektorem społecznym przypadają na początki transformacji systemowej. Dodać należy, że lokalna działalność społeczna w części wywodziła się z działalności Komitetów Obywatelskich. W okresie kształtowania się nowej rzeczywistości polityczno-ustrojowej można było obserwować pojawienie się dwóch podstawowych nurtów w obrębie wspomnianej społecznej działalności o charakterze lokalnym. Jeden $\mathrm{z}$ nich pozarządowy pozostawał $\mathrm{w}$ opozycji do tzw. politycznego nurtu samorządowego. Obydwie strony u progu transformacji systemowej uczyły się podstaw demokracji nie rozumiejąc specyfiki działania drugiej strony. ${ }^{6}$ Dodać należy, że istniejące rozwiązania w zakresie wspierania inicjatyw społecznych ze strony odrodzonego w 1990 roku samorządu terytorialnego opierały się na uznaniowych sposobach dystrybucji środków. Wciąż uprzywilejowanymi organizacjami społecznymi pozostawały kluby sportowe i straże pożarne stanowiące istotny element społecznej aktywności na poziomie lokalnym. $Z$ uwagi na brak regulacji prawnych, które określałyby zasady i formy współdziałania, w następnych latach zaczęto podejmować na szczeblu gmin działania w kierunku nawiązywania relacji z sektorem pozarządowym. Konsekwencją czego było pojawienie się dwóch modeli współpracy. Jeden określany jako sponsorski zakładał wydzielenie określonej części środków na organizacje pozarządowe. Drugi określany mianem zadaniowego wskazywał na konieczność

5 Dz.U. z 2014 r. Poz. 1118.

6 Poradnik modelowej współpracy administracji publicznej i organizacjami pozarządowymi, Wydawnictwo Sieć Wspierania Organizacji Pozarządowych SPLOT, Warszawa 2012, s. 18. 
dokonania uzgodnień pomiędzy administracją i organizacjami pozarządowymi w zakresie podziału środków na podstawie uchwalonego budżetu. ${ }^{7}$

Należy zauważyć, że do 1999 roku podejmowane działania dotyczące poszukiwania modelu współpracy pomiędzy administracją publiczną i organizacjami pozarządowymi miały charakter oddolnych inicjatyw. Brak rozwiązań systemowych skutkował tym, że w niektórych gminach budowanie relacji z sektorem pozarządowym było oparte jedynie na zasadach dystrybucji środków finansowych, w innych zaś zaczęto podejmować próby określania zasad i form przyszłego współdziałania. Wskazać należy również, że pierwsze działania legislacyjne w kierunku określenia wzajemnych relacji pomiędzy sektorem publicznym i sektorem organizacji pozarządowym zostały podjęte w 1996 roku z inicjatywy ówczesnej koalicji rządowej SLD-PSL-UP. Jednakże brak porozumienia ze strony ministerstwa finansów i ministerstwa pracy i polityki społecznej uniemożliwił dokończenie tych prac. Reasumując wypada stwierdzić, że zmiany ustrojowe i przeobrażenia systemowe zapoczątkowane w 1990 roku odrodzeniem instytucji samorządu terytorialnego bez wątpienia wywarły niekwestionowany wpływ w kształtowaniu podstaw społeczeństwa obywatelskiego wyrażającego się w rozwoju organizacji pozarządowych. Pobudzanie aktywności społecznej w procesie budowania wzajemnych relacji pomiędzy sferą publiczną i sferą pozarządową w tym okresie przyniosło w konsekwencji wypracowanie określonych standardów współdziałania w następnym okresie. Określenie prawnych i instytucjonalnych podstaw wspólpracy administracji publicznej z organizacjami pozarządowymi nastąpiło dopiero w 2003 roku na skutek uchwalenia ustawy o działalności pożytku publicznego i wolontariacie. Uporządkowanie relacji pomiędzy sferą instytucji samorządu terytorialnego i organizacjami pozarządowymi zostało dodatkowo wzmocnione na skutek akcesji Polski do Unii Europejskiej. Postrzeganie podmiotów trzeciego sektora w kategoriach partnerskich korespondowało bowiem $\mathrm{z}$ unijnymi regulacjami prawnymi. ${ }^{8}$

Regulacja będąca fundamentem działalności i współpracy sektora publicznego i pozarządowego z 2003 roku, wyraźnie wskazuje, że obowiązek współpracy opiera się na kilku kluczowych zasadach tj. zasadzie pomocniczości (subsydiarności), suwerenności i partnerstwa, efektywności, uczciwej konkurencji oraz legalności. Zasada subsydiarności jest jedną z zasad ustrojowych państwa usytuowaną w preambule Konstytucji RP. ${ }^{9}$ Wskazać należy, że stanowi ona podstawę do określania współpracy między władzami publicznymi, a niezależnymi pod-

\section{Ibidem, s. 18-19.}

8 S. Mocek, Dobre praktyki współpracy między administracją publiczną i organizacjami pozarządowymi (z wykorzystaniem analizy jakościowej), sierpień 2011, s. 11. Projekt partnerski: Model współpracy administracji publicznej i organizacji pozarządowych - wypracowanie i upowszechnienie standardów współpracy (www. civitas.edu.pl/pub/nasza_uczelnia/projekt_badania/ model_wspólpracy/ekspertyza/\%20/dobre\%20praktyki\%).

$9^{-}$Art. 12 Konstytucji stanowi: „Rzeczpospolita zapewnia wolność tworzenia i działania związków zawodowych, organizacji społeczno-zawodowych rolników, stowarzyszeń, ruchów obywatelskich, innych dobrowolnych zrzeszeń i fundacji”. 
miotami, która powinna służyć wzajemnemu skutecznemu uzupełnianiu się tych podmiotów w realizacji zadań publicznych. ${ }^{10}$ Podkreślić należy również, że organy jednostek samorządu terytorialnego podejmując współpracę z organizacjami pozarządowymi wspierają ich działalność. Natomiast organizacje pozarządowe stają się faktycznymi partnerami administracji samorządowej w wykonywaniu zadań publicznych. Realizacja zasady subsydiarności pozostaje w ścisłym związku z zasadą suwerenności, która ma na celu respektowanie autonomiczności i odrębności podmiotów podejmujących współpracę. Praktyczny wymiar tej zasady z perspektywy organizacji pozarządowych ma zapewnić ich prawo do samodzielnego definiowania i rozwiązywania problemów mieszczących się w obszarze spraw publicznych. Współpraca organizacji pozarządowych z podmiotami władzy publicznej na wszystkich szczeblach podziału terytorialnego państwa odbywa się na zasadzie partnerstwa. Zakłada ona, że aktywne uczestnictwo zarówno po stronie sektora publicznego jak również sektora pozarządowego $\mathrm{w}$ realizacji zadań wynikających ze współpracy. Dotyczy to w szczególności rozpoznawania problemów społecznych i określaniu sposobów ich rozwiązywania. ${ }^{11}$ Należy zauważyć, że zasada partnerstwa powinna sprowadzać się do traktowania organizacji pozarządowych w kategoriach partnera, a nie li tylko wyłącznie klienta administracji publicznej. Praktyka weryfikuje jednak właściwe rozumienie powyższej zasady z uwagi na fakt, że współpraca obydwu aktorów sprowadza się w przeważającej większości do zlecania zadań publicznych organizacjom pozarządowym. Realizacja zadań publicznych powinna opierać się na zasadzie przede wszystkim efektywności postrzeganej w kategoriach prawidłowego i ekonomicznego ich wykonania. Uzyskanie efektywności jest możliwe zarówno na etapie wyboru oferty, jak też na etapie oceny i kontroli realizacji danego zadania publicznego i osiągnięcia zakładanych efektów. ${ }^{12} \mathrm{~W}$ grupie analizowanych zasad współpracy istotne miejsce zajmuje zasada uczciwej konkurencji. Wiąże się ona z obowiązkiem stosowania przez lokalne podmioty władzy publicznej jednakowych przesłanek warunkujących przystąpienie organizacji pozarządowych do konkursu i składania ofert. W odniesieniu zaś do podmiotów sektora pozarządowego powyższa zasada koresponduje z zasadą efektywności i powinna wyrażać się w dążeniu do zmniejszania kosztów i jednocześnie wzrostu świadczonych usług publicznych. Podejmowanie współpracy z organizacjami pozarządowymi powinno być zgodnie z zasadą jawności, powszechnie dostępne i zrozumiałe

${ }^{10} \mathrm{~J}$. Blicharz, komentarz do ustawy o działalności pożytku publicznego i wolontariacie [w:] Ustawa o działalności pożytku publicznego i wolontariacie. Ustawa o spółdzielniach socjalnych. Komentarz, System Informacji prawnej Lex, 2012.

${ }^{11}$ Szerzej: Zasady współpracy organizacji pozarządowych z jednostkami samorządu terytorialnego. Poradnik (witrynawiejska.org.p1/.../zasady\%20wspolpracy\%20NGO\%20z\%20JS.pdf)

${ }_{12}$ J. Kotowski, A. Skibiński, Współpraca z organizacjami pozarządowymi- zmiana regulacji panaceum na wszystko... ale czy na pewno [w:] Rola organizacji pozarządowych w kształtowaniu społeczeństwa obywatelskiego. Doświadczenia i wyzwania, praca zbiorowa pod redakcją J. Babiaka, W. Sługockiego, Dom Wydawniczy Elipsa, Warszawa 2009, s. 59. 
zarówno w przedmiocie procedury jej nawiązywania, a następnie w odniesieniu do realizacji konkretnych zadań publicznych i wysokości przyznanych na ten cel środków. Ostatnia z wymienionych zasad określona w przepisach ustawy o działalności pożytku publicznego i wolontariacie przewiduje konieczność podejmowania przez obydwie strony współpracy wszelkich działań zgodnie z obowiązującymi przepisami prawa. Ustawodawca w powołanej wyżej ustawie sformułował również określone formy współpracy między jednostkami samorządu terytorialnego, a organizacjami pozarządowymi. Należy podkreślić, że mają one z jednej strony charakter finansowy, który sprowadza się do zlecania zadań publicznych oraz do zawierania umów o wykonanie inicjatywy lokalnej, czy też do zawierania tzw. partnerskich. $Z$ drugiej natomiast posiadają one wymiar pozafinansowy w zakresie wzajemnego informowania się, konsultowania aktów normatywnych oraz powoływania wspólnych zespołów doradczo-inicjatywnych. Warto dodać, że niektóre $\mathrm{z}$ wymienionych wyżej form współpracy, a mianowicie konsultowanie aktów prawnych z radami pożytku publicznego, wykonanie inicjatywy lokalnej oraz umowy partnerstwa zostały wprowadzone przez ustawodawcę w związku z nowelizacją w 2010 roku przepisów ustawy o działalności pożytku publicznego i wolontariacie. Określone w ustawie formy współpracy nie mają charakteru zamkniętego. Co oznacza, że istnieje możliwość kształtowania współdziałania w innych formach niż wymienione w ustawie. Dotyczą one podejmowania przez jednostki samorządu terytorialnego działań w zakresie doradztwa, czy też udzielania pomocy merytorycznej przy opracowywaniu projektów oraz w odniesieniu do udzielania informacji o istnieniu innych źródeł finansowania. ${ }^{13}$ Zlecanie zadań organizacjom pozarządowym wydaje się być podstawową formą analizowanej współpracy. Wskazać należy, że może ono polegać na tzw. powierzeniu wykonania zadań publicznych i udzieleniu dotacji na ten cel albo na tzw. wsparciu, które wyraża się w dofinasowaniu ich realizacji. Wsparcie finansowe ma miejsce wówczas, kiedy inicjatorem wykonania zadania publicznego jest organizacja pozarządowa. Zarówno powierzenie, jak też wspieranie realizacji zadań publicznych odbywa się w drodze ogłoszenia otwartego konkursu. Inny tryb niż ofertowy obowiązuje w sytuacji, kiedy inicjatorem jest organizacja pozarządowa i po spełnieniu łącznie dwóch przesłanek. Jedna z nich dotyczy wysokości dofinansowania zadania publicznego, które nie może przekroczyć 10 tys. złotych. Druga natomiast dotyczy okresu realizacji zadania, który nie może wynosić więcej jak 90 dni. Współpraca między jednostkami samorządu terytorialnego i organizacjami pozarządowymi odbywa się na podstawie tzw. programów współpracy. Warto dodać, że $\mathrm{w}$ aktualnym porządku prawnym mamy do czynienia z rocznymi i wieloletnimi programami współpracy. Pierwsze z nich mają charakter obligatoryjny i są uchwalane przez organy stanowiące jednostek samorządu terytorialnego tj. radę gminy, radę powiatu i sejmik województwa po wcześniejszych konsultacjach

${ }^{13}$ J. Blicharz, Komentarz do ustawy o działalności pożytku publicznego i wolontariacie..., art. 5. 
z organizacjami pozarządowymi. ${ }^{14}$ Drugie zaś, jako tzw. wieloletnie programy współpracy mają jedynie charakter fakultatywny i są uchwalane na okres 5 lat. ${ }^{15}$ Wracając do pozafinansowych form współdziałania warto wskazać, że kluczowe i zarazem podstawowe znaczenie posiada wzajemne informowanie się o planowanych kierunkach działalności. Ta forma współpracy pozwala kształtować trwałe relacje między władzami publicznymi i organizacjami pozarządowymi. Konsultowanie projektów aktów normatywnych w dziedzinach, które dotyczą działalności statutowej organizacji pozarządowych należy postrzegać w kategoriach sprawowania przez podmioty sektora pozarządowego społecznej kontroli nad działalnością administracji samorządowej czyniąc w ten sposób jej działania po pierwsze bardziej transparentnymi, po drugie bardziej skutecznymi. Kategoria pozafinansowych forma współdziałania pomiędzy jednostkami samorządu terytorialnego i organizacjami trzeciego sektora obejmuje tworzenie zespołów o charakterze doradczym i inicjatywnym. Ustawodawca w powołanej wyżej ustawie nie wskazał procedury ich powoływania oraz zakresu ich kompetencyjności. Jedyne wskazanie dotyczy zakresu ich działania. W skład zespołów doradczych i inicjatywnych powinni wchodzić przedstawiciele organizacji pozarządowych oraz przedstawiciele organów administracji publicznej. Przykładem tego typu zespołów są rady działalności pożytku publicznego, usytuowane na każdym szczeblu administracji samorządowej, funkcjonujące odpowiednio, jako wojewódzkie, powiatowe i gminne rady działalności pożytku publicznego przy ich organach wykonawczych. Wydaje się, że współpraca jednostek samorządu terytorialnego $\mathrm{z}$ organizacjami pozarządowymi znajduje trwałe podstawy $\mathrm{w}$ analizowanej ustawie o działalności pożytku publicznego i wolontariacie w zakresie sformułowanych w niej zasad i możliwych form współpracy. Niemniej fakt ten z całą pewnością nie przesądza o jakości podejmowanej współpracy. Wydaje się, że uzyskanie pożądanych efektów współpracy jest uzależnione od właściwego wyznaczania celów, definiowania problemów, poszukiwania skutecznych sposobów ich rozwiązywania oraz od wzajemnego dzielenia się wiedzą w zakresie budowania relacji międzysektorowych. ${ }^{16}$

${ }^{14}$ Art. 5(a) ustawy z dnia 24 kwietnia 2003 roku o działalności pożytku publicznego i wolontariacie.

${ }^{15} \mathrm{Na}$ skutek nowelizacji ustawy o działalności pożytku publicznego i wolontariacie z dnia 22 stycznia 2010 roku o zmianie ustawy o działalności pożytku publicznego i o wolontariacie oraz niektórych innych ustaw (Dz.U.2010 r. nr 28, poz. 146.)., wprowadzono wieloletnie programy współpracy na zasadzie fakultatywności.

${ }^{16}$ E. Bogacz-Wojtanowska, Współczesne problemy towarzyszące współdziałaniu organizacji pozarządowych z jednostkami samorządu terytorialnego [w:] Dziesięć lat reformy ustrojowej administracji publicznej w Polsce, pod red. J. Parachomiuka, b. Ulijasza, E. Kruka, Wyd. Wolters Kluwer, Warszawa 2009, s. 655. 


\section{W POSZUKIWANIU POŻĄDANEGO MODELU WSPÓŁPRACY MIĘDZY JEDNOSTKAMI SAMORZĄDU TERYTORIALNEGO I ORGANIZACJAMI POZARZĄDOWYMI}

Uzyskanie poprawy we wzajemnych relacjach pomiędzy administracją samorządową, a trzecim sektorem jest zależne od wypracowania określonego modelu współpracy. Dzięki temu jest możliwe skuteczniejsze wykonywanie zadań publicznych zarówno przez daną wspólnotę samorządową, jak również przez organizacje pozarządowe. Model taki został wypracowany z udziałem przedstawicieli różnych środowisk ${ }^{17}, \mathrm{w}$ związku z realizacją projektu: „Model współpracy administracji publicznej i organizacji pozarządowych- wypracowanie i upowszechnienie standardów współpracy". Należy dodać, że stworzenie modelu zostało poprzedzone wstępnymi badaniami jakościowymi z udziałem przedstawicieli samorządów i organizacji pozarządowych. Pozwoliły one uzyskać wiedzę empiryczną w zakresie dotychczasowej współpracy międzysektorowej i przygotowania zasadniczego narzędzia badań jakim był Indeks Jakości Współpracy. Powstał on na zamówienie Ministerstwa Pracy i Polityki Społecznej, jako instrument, dzięki któremu jest możliwe dokonanie oceny jakości współpracy międzysektorowej, a następnie planowanie polityki państwa w przedmiocie wspierania współpracy międzysektorowej. Indeks Jakości Współpracy obejmuje sześć obszarów tj, istnienie podstawowej infrastruktury współpracy, publiczną dostępność elementów infrastruktury, współpracę finansową, współpracę pozafinansową, wiedzę i opinie organizacji pozarządowych na temat uwarunkowań współpracy, zadowolenie organizacji pozarządowych ze współpracy z samorządem..$^{18}$ Niezadawalający poziom współpracy sektora publicznego i społecznego wynika $\mathrm{z}$ dokonanego w ramach indeksu jakości współpracy pomiaru z użyciem wskaźnika Dystans do Celu (DdC). Wskaźnik ten obrazuje maksymalny odsetek punktów wyrażający jakość współpracy możliwy do osiągnięcia przy aktualnej konstrukcji indeksu. Przy czym maksymalna wielkość wskaźnika nie jest równa wartości 100\% i tym samym nie jest równoznaczna $z$ osiągnięciem stanu współpracy idealnej lecz $\mathrm{z}$ osiągnięciem tego co w danej chwili mierzy indeks. ${ }^{19}$ Przeprowadzone badania utrwaliły tezę, że w relacjach miedzy sektorem publicznym a społecznym moż-

${ }^{17}$ Instytut Spraw Publicznych, Collegium Civitas, Sieć Wspierania Organizacji Pozarządowych SPLOT, Związek Miast Polskich, Forum Aktywizacji Obszarów Wiejskich oraz Departament Pożytku Publicznego w Ministerstwie Pracy i Polityki Społecznej.

${ }^{18}$ M. Dutkiewicz, Indeks Jakości Współpracy-praktyczne narzędzie zarządzania współpracą międzysektorową, Trzeci Sektor, numer specjalny 2011/2012, s. 77.

${ }_{19}$ M. Dutkiewicz, G. Makowski, Współpraca miedzy organizacjami pozarządowymi i administracją samorządową. Problemy, wyzwania i rekomendacje, s. 3-4. Ekspertyza przygotowana przez Instytut Spraw Publicznych w ramach projektu; „Model współpracy administracji publicznej i organizacji pozarządowych -wypracowanie i upowszechnienie standardów współpracy, realizowanego w ramach Priorytetu V Dobre rządzenie, działanie 5.4 Rozwój potencjału trzeciego sektora, Poddziałanie 5.4.1 Wsparcie systemowe dla trzeciego sektora Programu Operacyjnego Kapitał Ludzki. 
na zauważyć istnienie trzech zasadniczych grup problemów, które sprowadzają się do nierówności stron, niedostatku kultury współpracy, braku przedstawicieli organów stanowiących w procesie współpracy. ${ }^{20}$ Jak zauważa M. Dutkiewicz zasadniczą przyczyną nierówności stron współpracy jest niski poziom wiedzy merytorycznej organizacji pozarządowych w zakresie prawa, ekonomii, promocji i słabym zapleczu infrastrukturalnym. ${ }^{21} \mathrm{~W}$ konsekwencji dochodzi bowiem do zakłócenie relacji międzysektorowych opartych na zasadzie partnerstwa i uprzywilejowania podmiotów reprezentujących sferę publiczną. Dążenie do wzmocnienia podmiotowości organizacji pozarządowych poprzez fakt powierzania a nie wspierania wykonania zadań publicznych może przyczynić się wyeliminowania tego problemu. ${ }^{22}$ Wskazać również należy, że problem nierówności stron wynika $\mathrm{z}$ faktu, że organizacje pozarządowe $\mathrm{z}$ uwagi na trudności finansowe zabiegają o nawiązanie współpracy z sektorem publicznym uzyskując status petenta, a nie partnera. Z punktu widzenia podmiotów administracji samorządowej organizacje pozarządowe nie są pierwszoplanowym partnerem w budowaniu relacji z otoczeniem zewnętrznym. W przeprowadzonych badaniach zwrócono uwagę na powtarzający się obszar zlecanych organizacjom pozarządowym zadań, który dotyczy zwłaszcza sportu i kultury. W obszarze pomocy społecznej i zdrowia współpraca kształtuje się na poziomie dużo niższym. Wydaje się, że jednostki samorządu terytorialnego zlecając wykonanie określonych zadań organizacjom pozarządowym wypełniają li tylko wyłącznie obowiązek znajdujący umocowanie w przepisach ustawy o działalności pożytku publicznego i wolontariacie. Takie podejście z całą pewnością nie sprzyja budowaniu partnerskiej współpracy. Brak dostatecznej kultury współpracy ujawnia się w sferze obyczajowości, codziennej praktyce, nieufności stron oraz braku wspólnego zrozumienia istoty i specyfiki działania. Problem braku kultury współdziałania może zostać rozwiązany poprzez wzmocnienie działań edukacyjnych, wprowadzenie system regularnych szkoleń, warsztatów, czy w końcu wymiany pracowników, stażystów. ${ }^{23}$ Kluczowym instrumentem, który może przyczynić się do poprawy kultury współdziałania jest instytucja kompaktu. Kompakt to nic innego jak pewien rodzaj umowy pomiędzy władzą publiczną, a obywatelami zrzeszonymi w organizacjach pozarządowych. Dzięki tej instytucji możliwe jest określenie zasad współpracy oraz wzajemnych zobowiązań obydwu partnerów i w konsekwencji dążenie do budowania silnego

${ }^{20}$ Szerzej, A. Duk-Majewska, D. Strus, Aktualne problemy współpracy jednostek samorządu terytorialnego z organizacjami pozarządowymi [w:] Internacjonalizacja Administracji Publicznej, redakcja naukowa Z. Czarnik, J. Posłuszny, L. Żukowski, Wyd. Wolters Kluwer, Warszawa 2015, s. $445-446$.

${ }^{21}$ M. Dutkiewicz, Lokalne uwarunkowania współpracy międzysektorowej, Trzeci Sektor, nr specjalny 2011/2012 w stronę partnerskiej współpracy, s. 22.

${ }^{22}$ M. Dutkiewicz, M. Makowski, Współpraca między organizacjami pozarządowymi..., s. 3 i n.

${ }^{23}$ Ibidem, s. 3 i n. 
i autonomicznego społeczeństwa obywatelskiego. ${ }^{24}$ Wyniki badań potwierdziły jeszcze jedną prawidłowość, a mianowicie słabą współpracę na poziomie lokalnym szczególnie na obszarach gmin wiejskich i wiejsko-miejskich. Wartość wskaźnika (DdC) była najniższa w stosunku do pozostałych jednostek samorządu terytorialnego. Pożądane są zatem zmiany w kierunku uelastycznienia współpracy na tym szczeblu administracji samorządowej poprzez preferowanie tzw. dobrych praktyk. Na podstawie Raportu Jakość współpracy między organizacjami pozarządowymi i administracją publiczną, jaki został opracowany w 2011 roku przez Instytut Spraw Publicznych wynika, że do głównych przeszkód we współpracy zalicza się problemy w zakresie kooperacji między administracją publiczną, a trzecim sektorem oraz słabość i bierność trzeciego sektora, a także występujący brak kompetencji zarówno ze strony władzy publicznej, jak również organizacji pozarządowych. Nadmierna biurokracja oraz brak znajomości mechanizmów działania to kolejne przeszkody we współpracy. ${ }^{25}$

\section{RELACJE JEDNOSTEK SAMORZĄDU TERYTORIALNEGO Z ORGANIZACJAMI POZARZĄDOWYMI NA PODSTAWIE BADAŃ TERENOWYCH (WOJEWÓDZTWA MAZOWIECKIEGO I LUBELSKIEGO)}

W tej części opracowania zostaną zaprezentowane wyniki badań, jakie zostały uzyskane w 2015 roku w oparciu o przeprowadzone badania ankietowe z przedstawicielami administracji samorządowej z obszaru województwa mazowieckiego i lubelskiego, a w szczególności gmin działających w powiecie radomskim, zwoleńskim, lipskim, oraz z przedstawicielami administracji samorządowej powiatu łosickiego i siedleckiego, a także gmin Łuków, Siedlce, Stok Lacki). Pytania ankietowe dotyczyły w szczególności: stosowanych przez samorządy form współpracy z podmiotami trzeciego sektora, obszarów zlecanych bądź powierzanych organizacjom pozarządowym zadań, trybu zlecania zadań publicznych, konsultowania z organizacjami pozarządowymi programów współpracy, utworzenia stanowiska ds. kontaktów z przedstawicielami organizacji pozarządowych, barier i korzyści wynikających z podejmowanej współpracy, stosowania tzw. dobrych praktyk współdziałania w kierunku wzmocnienia kultury współdziałania. W kontekście stosowanych form współpracy samorządu terytorialnego z organizacjami pozarządowymi wszystkie jednostki samorządu terytorialnego powiatu radomskiego, zwoleńskiego i lipskiego w latach 2012-2014 współpracowały z organizacjami pozarządowymi i innymi podmiotami, prowadzącymi działalność pożytku pu-

${ }^{24}$ G. Makowski, Kompaktowa kultura współpracy, Trzeci Sektor, numer specjalny 2011/2012 W stronę partnerskiej współpracy, s. 34 i n.

${ }^{25}$ P. Nosal, Przeszkody we współpracy, organizacje pozarządowe w relacjach z jednostkami samorządu terytorialnego na przykładzie Województwa Wielkopolskiego, Trzeci Sektor, nr 32 (1/2014), s. 115. 
blicznego. Badane jednostki najczęściej stosowały kilka form współpracy, choć wśród badanych znalazły się dwie jednostki, które stosowały w praktyce tylko jedną formę współpracy, a mianowicie zlecanie obsługi otwartych konkursów ofert oraz regranting. Najczęściej stosowaną formą współdziałania jest konsultowanie programów współpracy z organizacjami pozarządowymi, chociaż znalazły się trzy, które nie wywiązują się z tego obowiązku. 20 jednostek samorządu terytorialnego stosuje również otwarte konkursy ofert na zlecanie zadań publicznych, natomiast 5 jednostek samorządu terytorialnego nie stosuje tej formy współpracy. Najczęściej wskazywane przez respondentów obszary zadań zlecanych organizacjom pozarządowym $\mathrm{i}$ innym podmiotom prowadzącym działalność pożytku publicznego to sport rekreacja i turystyka. Rzadziej były wskazywane zadania dotyczące opieki i wypoczynku dzieci, integracji mieszkańców, edukacji, oświaty, kultury oraz pomocy społecznej. Incydentalnie wskazano na zlecanie zadań publicznych w zakresie ekologii i wsparcia osób niepełnosprawnych. Najczęściej jednostki samorządu terytorialnego zlecają zadania stowarzyszeniom rejestrowym i stowarzyszeniom zwykłym. Wszystkie jednostki samorządu terytorialnego opracowują roczne programy współpracy, a 5 ankietowanych stosowało w ubiegłych dwóch latach wieloletnie umowy na realizację zadań publicznych w zakresie sportu, edukacji, pomocy społecznej oraz wsparcia organizacji pozarządowych. W przedmiocie monitorowania i oceny zleconych zadań publicznych najczęściej wskazywaną formą stanowią sprawozdania merytoryczne i finansowe. Połowa badanych jednostek samorządu terytorialnego stosuje wizyty i kontrole. W odniesieniu zaś do przesłanek, jakimi kierują się samorządy zlecając organizacjom pozarządowym zadania publiczne ankietowani wskazali: wzajemną otwartość obydwu stron, przychylność, dobre kontakty interpersonalne, korzyść dla urzędników w postaci mniejszych obowiązków, efektywniejsze wykorzystanie środków publicznych, aktywność ze strony samych organizacji, dobre doświadczenia płynące z dotychczasowej współpracy, chęć pozbycia się przez samorząd obowiązków, zagwarantowanie środków finansowych z budżetu jednostki samorządu terytorialnego. W większości badanych samorządów nie istnieje wyodrębniona komórka ds. współpracy z organizacjami pozarządowymi, Współpracą ta zajmują się wydziały promocji poszczególnych urzędów. W grupie najczęściej wymienianych barier z perspektywy administracji samorządowej utrudniających współpracę z organizacjami pozarządowymi wskazywano na niewystarczające środki finansowe oraz małą liczbę funkcjonujących na danym terenie organizacji pozarządowych oraz brak aktywnych liderów organizacji pozarządowych i postawa roszczeniowa organizacji pozarządowych względem administracji samorządowej. Niewielka liczba badanych jednostek samorządu terytorialnego (3 jednostki samorządu gminnego działające na terenie województwa mazowieckiego) wskazało na inne niż finansowe formy współpracy dotyczące wzajemnej wymiany informacji o planowanych kierunkach działalności i realizowanych zadaniach. W tym obszarze badane jednostki konsultowały z organizacjami pozarządowymi projekty aktów prawa miejscowego $\mathrm{w}$ dziedzinach dotyczących ich działalności statutowej oraz udostępniały pomieszczenia, lokale, 
nieruchomości gminne, obiekty sportowe w celu organizowania nieodpłatnych spotkań na rzecz społeczności lokalnej. W żadnej z badanych jednostek samorządu terytorialnego nie przystąpiono do realizacji inicjatywy lokalnej, zgodnie z którą mieszkańcy mogą z własnej inicjatywy złożyć wniosek o realizację zadania publicznego. Uzyskane wyniki w zakresie wzajemnej wymiany informacji pokazały, że dominująca formą jest rozpowszechnianie informacji drogą elektroniczną za pomocą strony internetowej BIP w niewielkim stopniu wykorzystuje się tradycyjne sposoby wymiany informacji. W kontekście wykorzystywania tzw. dobrych praktyk współdziałania, mających na celu wzmocnienie kultury współdziałania w niewielkiej ilości ankietowanych jednostek samorządu terytorialnego są podejmowane działania edukacyjne, szkoleniowe i warsztatowe. Tylko jedna jednostka samorządu terytorialnego wskazała na potrzebę organizowania szkoleń organizacji pozarządowych w zakresie księgowości, pisania projektów pozyskiwania funduszy na działalność oraz prowadzenie badań mających na celu rozpoznanie potrzeb i oczekiwań organizacji pozarządowych działających na jej obszarze właściwości.

Konkludując, uzyskane wyniki z przeprowadzonych badań ankietowych uprawniają do podsumowania i sformułowania wniosków końcowych korespondujących z postawionymi przez autora tezami. Przeprowadzona analiza dotycząca wzajemnych relacji pomiędzy sektorem publicznym i sektorem społecznym wskazuje, że w dalszym ciągu dominującą formą współpracy jest zlecanie zadań publicznych. Niepokojące wydaje się zjawisko zlecania zadań publicznych tylko w niektórych obszarach tj. w zakresie sportu, rekreacji, kultury z marginalnym powierzaniem organizacjom trzeciego sektora innych ważnych z punktu widzenia potrzeb społeczności lokalnej zadań, mieszczących się w sferze pomocy społecznej, w tym wsparcia dla osób wykluczonych społecznie i osób niepełnosprawnych oraz w zakresie ochrony środowiska. Ich finansowanie w całości na co wskazują wyniki badań przez jednostki samorządu terytorialnego wpływa z jednej strony na osłabienie partnerskich relacji i nierówność stron współpracy, sytuując organizacje pozarządowe w roli klienta a nie partnera administracji samorządowej. Możliwość pozyskania środków finansowych przez podmioty sektora społecznego wydaje się być „walką o przetrwanie” dla większości organizacji, które nie dysponują potencjałem finansowym. Przeprowadzona analiza dowodzi, że jednostki samorządu terytorialnego nie korzystają w pełni z prawnych instrumentów współpracy o charakterze pozafinansowym. Instytucja konsultacji jest wykorzystywana przez wszystkie badane podmioty sektora publicznego przy tworzeniu programów współpracy. W niewielkim stopniu przedstawiciele administracji samorządowej przekazują organizacjom pozarządowym do konsultacji projekty aktów prawa miejscowego oraz inne dokumenty takie jak chociażby strategie rozwoju danej jednostki samorządu terytorialnego. Niewykorzystywana jest również możliwość powoływania wspólnych zespołów doradczych i inicjatywnych. Kolejny wniosek, jaki można wyprowadzić na podstawie badań ankietowych dotyczący jakości współpracy międzysektorowej jest związany z wielkością jednostki samorządu terytorialnego. Co oznacza, że im mniejsza jednostka podziału terytorialnego, tym współpracę z trzecim sektorem 
można określić jako słabą. Wydaje się, że właśnie na tych szczeblach wysiłki ze strony władzy lokalnej powinny polegać na wdrażaniu tzw. nieformalnych dobrych praktyk współpracy, którym powinny towarzyszyć przede wszystkim cykliczne i otwarte spotkania obydwu partnerów. Działania takie pozwoliłyby rozwijać kulturę współpracy i w konsekwencji przyczynić się do wzmocnienia potencjału merytorycznego i organizacyjnego organizacji pozarządowych. Pozytywnie należy ocenić fakt, że we wszystkich badanych jednostkach samorządu terytorialnego są opracowywane roczne programy współpracy z powolną, jak się wydaje tendencją do opracowywania wieloletnich programów współpracy, które na co należy zwrócić uwagę $w$ aktualnym porządku prawnym mają jedynie charakter fakultatywny. W kategoriach pozytywnych zmian należy również ocenić zlecanie zadań publicznych w trybie otwartych konkursów ofert i powoływania w tym celu komisji konkursowych złożonych z przedstawicieli samorządu i organizacji pozarządowych. Wydaje się, że mimo istniejących w dalszym ciągu niedoskonałości współpracy międzysektorowej jest ona postrzegana przez przedstawicieli sektora publicznego jako zadowalająca a nawet dobra.

\title{
RELATIONS BETWEEN THE PUBLIC SECTOR, A NON-GOVERNMENTAL SECTOR IN PERFORMING PUBLIC DUTIES.
}

\begin{abstract}
The aim of the study is to identify the current model of cooperation between local authorities and representatives of the third sector on the implementation of the tasks of a public nature based on research carried out at the initiative of the Public Utility Department at the Ministry of Labour and Social Policy and the author's own research. Analysis of inter-relations from the perspective of local government administration will be based on field research conducted. The results obtained in the author's development entitle to a few theses. Firstly, the existing model of interaction between the public sector and non-governmental sector, in principle, limited to the statutory outsourcing of public tasks non-public entities in recurring business areas, ie. In the field of sport, recreation and tourism. Secondly, cooperation in the smallest units of territorial division of the state (municipalities) seems to be the weakest. Thirdly, representatives of the local administration does not apply some of the solutions resulting from the Act on public benefit activity and volunteerism. Fourth, cross-sectoral cooperation does not include the implementation of joint projects using funds from external sources. Fifthly deficiencies in the cooperation undertaken due to the lack of cross-cultural interaction, insufficient knowledge about the specific activities of NGOs. The last thesis verified in the study concerns the indications of positive changes in the current model of cooperation.
\end{abstract}

Key words: NGOs, local government, public tasks, cross-sectoral cooperation, civil society 